\title{
KAJIAN SISTEM KEDARURATAN RADIOLOGI KOREA (CARE SYSTEM) DAN RENCANA PENGEMBANGAN SISTEM KEDARURATAN NUKLIR NASIONAL
}

\author{
AKHMAD KHUSYAIRI, YUDI PRAMONO \\ Direktorat Inspeksi Instalasi dan Bahan Nuklir \\ Badan Pengawas Tenaga Nuklir-BAPETEN \\ Jl. Gadjah Mada No. 8 Jakarta-Pusat
}

\begin{abstract}
Abstrak
KAJIAN SISTEM KEDARURATAN RADIOLOGI KOREA-CARE SYSTEM DAN RENCANA PENGEMBANGAN SISTEM KEDARURATAN NUKLIR NASIONAL. Radioaktivitas lingkungan merupakan salah satu aspek utama yang harus diperhatikan dalam konsep pengawasan terkait dengan pemanfaatan tenaga nuklir. Penggunaan teknologi informasi di bidang nuklir memberikan kontribusi yang signifikan terhadap antisipasi dan upaya-upaya proteksi masyarakat dan lingkungan. Sejak 1960-an Korea Selatan telah mengembangkan suatu sistem yang terintegrasi (Care system) guna membantu upaya-upaya proteksi manusia dan lingkungan dalam kondisi kedaruratan radiologi. Indonesia yang telah memiliki beberapa instalasi nuklir dan dimasa yang akan datang akan membangun dan mengoperasikan beberapa reaktor daya (PLTN), perlu mempersiapkan sejak dini sistem yang bisa memberikan dukungan teknis terkait dengan kedaruratan radiologi. Hikmah yang dapat diambil dari apa yang telah dilakukan Korea Selatan adalah bahwa Indonesia harus mempersiapkan sistem kedaruratan radiologi yang akan digunakan di Indonesia. Rancangan Peraturan Pemerintah tentang Sistem Kedaruratan Nuklir Nasional (RPP SKNN) yang sedang disusun belum menyentuh hal-hal teknis dan hanya pada aspek manajemen. Ketika hal teknis harus diatur maka perlu dipertimbangkan sistem (Technical Supporting System), organisasi pelaksana/operator, dan sumber daya manusia dari masing-masing instansi. Disamping itu BAPETEN harus memiliki sistem serupa yang independen dalam rangka pengawasan.
\end{abstract}

Kata kunci : sistem pendukung kedaruratan radiologi

\begin{abstract}
STUDY ON KOREAN RADIOLOGICAL EMERGENCY SYSTEM-CARE SYSTEM- AND NATIONAL NUCLEAR EMERGENCY PREPAREDNESS SYSTEM DEVELOPMENT. Care system; Radiological Emergency Supporting System. Environmental radiology level is the main aspect that should be concerned deal with the utilization of nuclear energy. The usage of informational technology in nuclear area gives significant contribution to anticipate and to protect human and environment. Since 1960s, South Korea has developed environment monitoring
\end{abstract}


system as the effort to protect the human and environment in the radiological emergency condition. Indonesia has possessed several nuclear installations and planned to build and operate nuclear power plants (PLTN) in the future. Therefore, Indonesia has to prepare the integrated system, technically enables to overcome the radiological emergency. Learning from the practice in South Korea, the system on the radiological emergency should be prepared and applied in Indonesia. However, the government regulation draft on National Radiological Emergency System, under construction, only touches the management aspect, not the technical matters. Consequently, when the regulation is implemented, it will need an additional regulation on technical aspect including the consideration on the system (TSS), the organization of operator and the preparation of human resources development of involved institution. For that purpose, BAPETEN should have a typical independence system in regulatory frame work.

Keywords: Computerized Technical Advisory Radiological Emergency System

\section{PENDAHULUAN}

\section{Latar Belakang}

Setiap pemanfaatan teknologi nuklir di berbagai bidang harus selalu mempertimbangkan resiko yang menyertainya. Penggunaan teknologi nuklir tersebut harus mempertimbangkan berbagai aspek, salah satu diantaranya adalah radioaktivitas lingkungan. Keselamatan merupakan hal utama yang harus diperhatikan dalam pemanfaatan tenaga nuklir. Aspek keselamatan yang tidak dijadikan prioritas utama dalam pemanfaatan tenaga nuklir akan memberikan dampak yang serius baik yang diterima pekerja, masyarakat maupun lingkungan.

Percobaan senjata nuklir di era perang dingin memberikan kontribusi negatif terhadap lingkungan. Akibat dari percobaan senjata nuklir memberikan dampak terhadap peningkatan tingkat (level) radioaktivitas lingkungan di sekitar lokasi percobaan. Kecelakaan Chernobyl juga salah satu kasus yang memberikan kontribusi pada peningkatan level radioaktivitas lingkungan. Pada hari yang sama, Swedia melaporkan terjadinya peningkatan level radioaktivitas lingkungan yang signifikan di wilayah negaranya.

Indikasi upaya percobaan senjata nuklir yang dilakukan Korea Utara juga memberikan informasi yang perlu dibuktikan lebih lanjut bahwa terjadi kontribusi peningkatan level radioaktivitas lingkungan di semenanjung Korea, oleh karenanya Korea Selatan melakukan upaya-upaya pemantauan radioaktivitas lingkungan sejak era 1960-an.

\section{Tujuan}

Kajian ini dilakukan untuk menganalisis kemungkinan penerapan sistem pendukung dalam upaya-upaya proteksi manusia dan lingkungan 
dalam kondisi kedaruratan radiologi, baik persiapan teknis maupun persiapan SDM yang akan berperan dalam sistem kedaruratan ini.

\section{Masalah}

Keselamatan merupakan prioritas utama dalam pemanfaatan tenaga nuklir. Pemantauan lingkungan terkait pemanfaatan tenaga nuklir mutlak harus dilakukan guna memberikan jaminan kepada masyarakat bahwa pemanfaatan tenaga nuklir aman dan selamat.

Dalam kondisi kedaruratan radiologi, pemantauan radioaktivitas lingkungan harus dilakukan dalam upaya-upaya perlindungan terhadap masyarakat dan lingkungan. Saat ini telah banyak digunakan suatu sistem pemantauan radioaktivitas lingkungan yang terkomputerisasi di berbagai negara untuk memberikan dukungan teknis, salah satu diantaranya adalah Korea Selatan. Indonesia yang telah memiliki dan mengoperasikan beberapa instalasi nuklir dan dimasa yang akan datang, akan membangun dan mengoperasikan PLTN harus menentukan sistem kedaruratan yang akan digunakan dengan mempertimbangkan sistem yang sudah ada di berbagai negara.

\section{Metodologi Kajian}

Metodologi yang digunakan dalam kajian ini adalah membandingkan antara sistem kedaruratan radiologi Korea yang telah ada dan sitem kedaruratan nuklir nasional yang saat ini sedang dikembangkan.

\section{TEORI/BAHAN}

\section{Hazard-Risk}

Tenaga nuklir, disamping memberikan manfaat terdapat potensi bahaya yang terkandung dibalik pemanfaatannya. Dalam pemanfaatan tenaga nuklir khususnya untuk pembangkit listrik, produk fisi merupakan salah satu hal yang harus diantisipasi agar tidak terjadi pelepasan ke lingkungan. hal ini disebabkan oleh selain aktivitasnya yang tinggi juga umur paroh dari produk fisi tersebut sangat panjang.

Dalam pengoperasian PLTN jenis LWR (light water reactor), produk fisi terkungkung dalam matrik bahan bakar di dalam kelongsong bahan bakar (Gambar 1). 


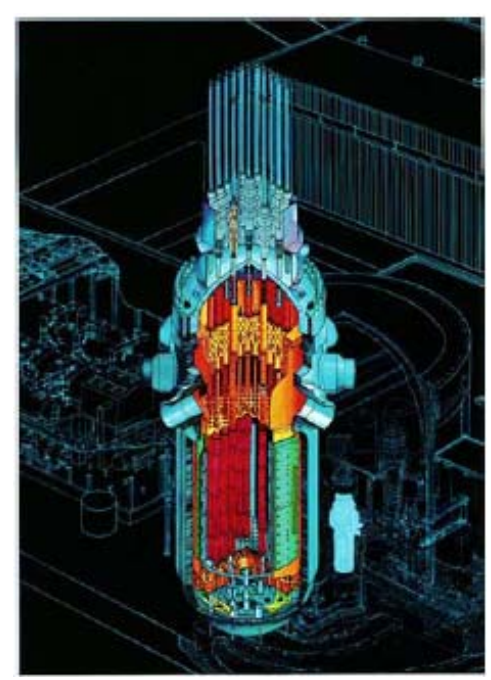

Gambar 1. Pressure Vessel PWR

Sistem proteksi yang menjamin tidak terlepasnya radioaktivitas ke lingkungan sudah dipersyaratkan pada tingkatan yang berlapis, seperti berbagai penghalang ganda yang pada sistem reaktor daya (pressure vessel, containment, dll). Namun demikian tetap diperlukan sistem pendukung lain yang menjamin produk fisi tetap terkungkung.

Pelepasan produk fisi ke lingkungan akan memberikan dampak yang cukup signifikan, jika hal ini terjadi maka harus dilakukan upaya-upaya untuk perlindungan manusia dan lingkungan.

\section{Organisasi Kedaruratan Korea Selatan}

Saat ini Korea Selatan telah membangun dan memiliki organisasi kedaruratan radiologi yang terdiri dari berbagai organisasi terkait, diantaranya adalah:

\section{Ministry of Science and Technology (MOST)}

Kementrian Ilmu Pengetahuan dan Teknologi Korea Selatan (MOST) adalah lembaga yang berkompeten tingkat nasional dalam kondisi kedaruratan radiologi. Terdapat tiga komite yang dikoordinasikan oleh Kementerian Ilmu Pengetahuan dan Teknologi Korea Selatan dalam hal kedaruratan radiologi, diantaranya adalah; Nuclear Emergency Management Committee (NEMC), Central Radiological Emergency Control Command (CRECC) dan Off-site Emergency Management Center (OEMC). Dalam hal kedaruratan radiologi, LEMC (Local Emergency Management Committee) terbentuk dan beroperasi, LEMC terdiri dari personel yang contoh yang tidak dikenal akan memberikan masalah relatif sulit bila diperlukan hasil kuantitatif ${ }^{[4,5]}$. 
berada dalam institusi terkait pada wilayah dimana terjadinya kedaruratan radiologi, misalnya Gubernur, Walikota/Bupati, serta Kepolisian setempat. LEMC bertanggung jawab terhadap pelaksanaan upaya-upaya perlindungan terhadap warga.

Off-Site Emergency Management Center (OEMC)

OEMC dibentuk untuk menjalankan sistem manajemen kedaruratan radiologi, mengumpulkan informasi dan memberikan laporan kepada lembaga yang berwenang. Disamping itu OEMC memberikan perintah dan mempunyai tugas melakukan mitigasi dampak. OEMC dipimpin oleh wakil menteri ilmu dan teknologi Korea Selatan (misalnya untuk kedaruratan radiologi dipimpin oleh Dirjen Biro Nuklir). Sedangkan Off-Site Emergency Management Center Advisory Committee (OEMCAC) merupakan komite yang terdiri dari personel dari instansi administratif setempat (Pemerintah Daerah setempat).

Korea Institute of Nuclear Safety (KINS)

KINS membentuk dan menjalankan ETACRP (Emergency Technical Advisory Center on Radiological Protection) untuk membantu memberikan dukungan teknis (saran/rekomendasi) terkait dengan upaya perlindungan terhadap masyarakat dan lingkungan yang dilakukan oleh NEMC dan LEMC serta melakukan kajian terkait dengan upaya yang dilakukan oleh pemegang izin dalam hal terjadinya kedaruratan radiologi. KINS menurunkan personelnya untuk melakukan survey lapangan guna melakukan pengukuran tingkat radioaktivitas lingkungan dan memberikan dukungan teknis kepada OEMC dan EOF (Emergency Operation Facility). Terkait dengan tugas lapangan yang dalam hal survey radioaktivitas lingkungan, KINS membentuk dan menjalankan KOTST (KINS' On-Site Technical Support Team).

KIRAMS

KIRAMS membentuk MSCRE (Medical Service Center on a Radiological Emergency) untuk memberikan bantuan medis pada penduduk disekitar tempat terjadinya kedaruratan radiologi yang terkena dampak juga bagi korban luka akibat kedaruratan radiologi. KIRAMS tidak hanya membentuk National Nuclear Emergency Medical Center (NNEMC) untuk memberikan pertolongan pertama akibat paparan radiasi tetapi juga membentuk National Nuclear Emergency Medical System (NNEMS).

\section{Care System}

Care system adalah suatu sistem pendukung kedaruratan radiologi yang telah terkomputerisasi yang telah dikembangkan dan dioperasikan oleh Korea Selatan. Care system mempunyai kemampuan untuk mendiagnosa 
kondisi instalasi sesaat setelah kejadian serta melakukan kajian tentang konsekuensi radiologi, identifikasi status kecelakaan, estimasi dispersi zat radioaktif, memprediksi area/wilayah yang berpotensi terkena dampak, serta melakukan estimasi dosis yang diterima masyarakat. Care system, terdiri dari beberapa modul yang bekerja secara terintegrasi (Gambar 2).

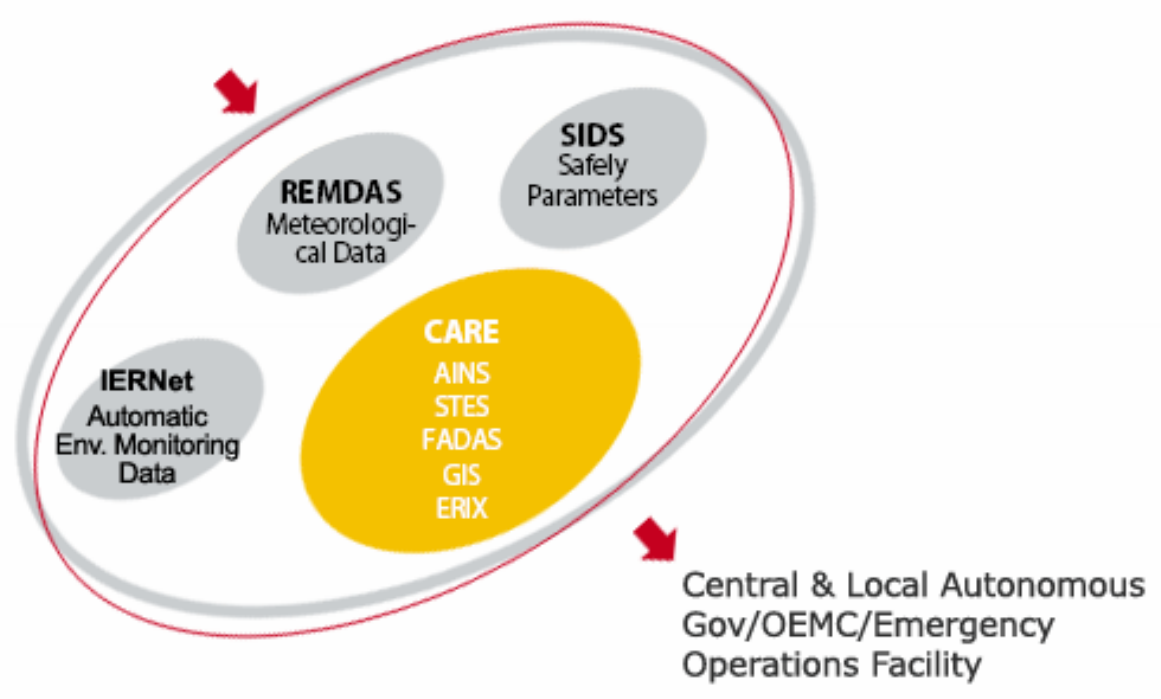

Gambar 2. Care System

(Anonim, 2007)

Safety Information Display System (SIDS)

SIDS system, mengumpulkan semua insiden maupun accident pada semua reaktor daya yang beroperasi dan memantau status operasi dari masingmasing reaktor daya yang ada. Pengumpulan data ini dilakukan setiap 10-20 detik. Pada kondisi kecelakaan radiologi, sistem ini akan berfungsi untuk melakukan analisis kondisi kecelakaan, memprediksikan proses dan konsekwensi setelah kecelakaan serta melakukan estimasi jangka waktu pemulihan. SIDS system, mengumpulkan dan menganalisa 200-300 parameter keselamatan kritis untuk masing-masing reaktor daya (Anonim, 2007). 

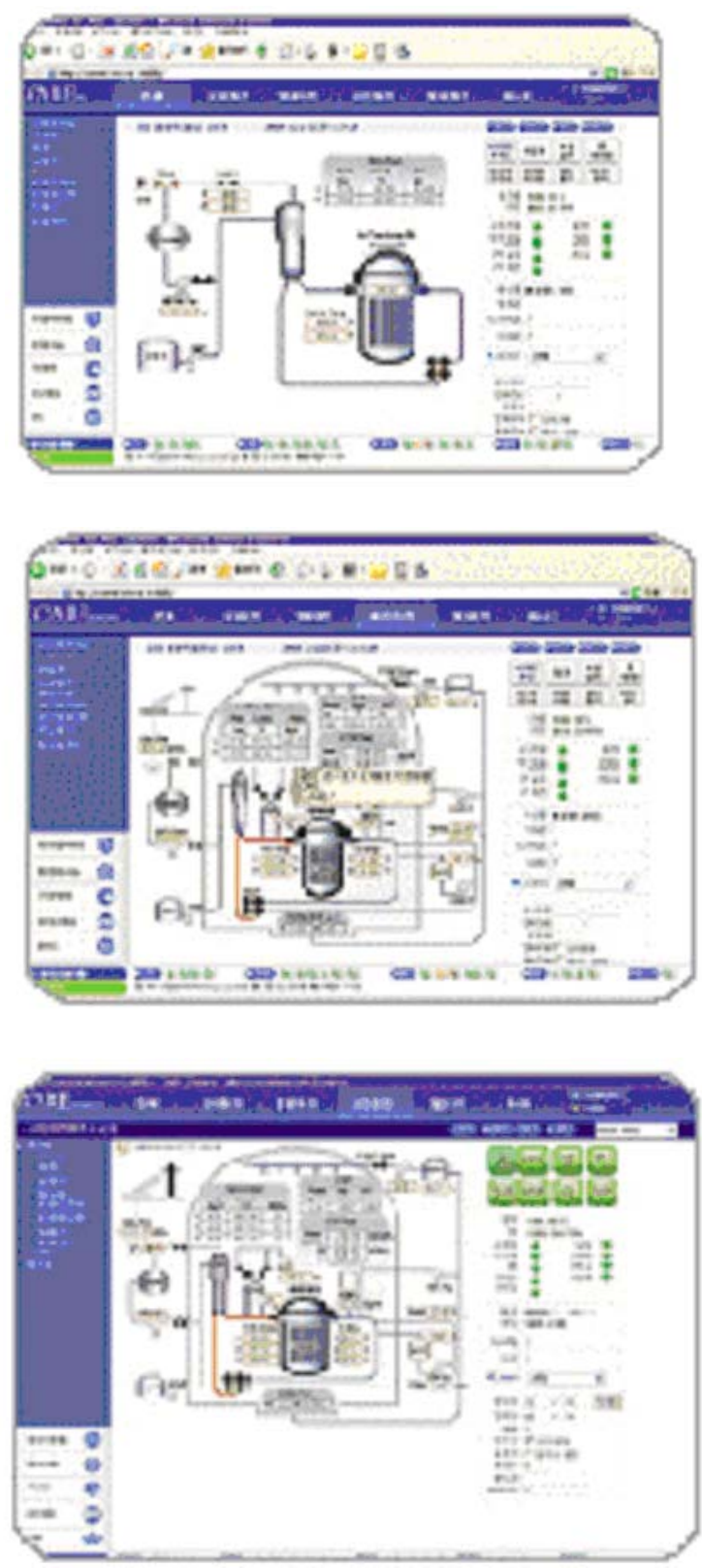

Gambar 3. Display SIDS

Radiological Emergency Meteorological Data Acquisition System (REMDAS)

REMDAS system, mengumpulkan informasi meteorologi area disekitar reaktor daya yang berasal dari AWS (Automatic Weather System) milik Korea Meteorological Administration (KMA) berdasarkan real time. Data 
terkumpul digunakan untuk melakukan estimasi dispersi material zat radioaktif di atmosfir (Anonim, 2007).

Pengumpulan data hasil observasi cuaca dilakukan setiap 10 menit, meliputi kecepatan angin, arah angin, temperatur, presipitasi, dll. Dari data yang terkumpul dilakukan mapping untuk mendapatkan medan angin 3 dimensi dengan memperhitungkan kondisi topografi dengan radius $40 \mathrm{~km}$ dari tapak reaktor daya (Gambar 4).

Integrated Environment Radiation Monitoring Network (IERNet)

IERNet system, memantau kecenderungan tingkat/level radioaktivitas lingkungan akibat dari kecelakaan radiologi ataupun nuclear fallout akibat aktivitas yang terjadi baik yang berada dari dalam negeri maupun dari luar negeri (Gambar 5). Jika terjadi peningkatan tingkat radioaktivitas yang tidak normal, sistem ini akan memberikan notifikasi pada institusi/lembaga tingkat nasional yang berkompeten, untuk membentuk suatu sistem tanggap darurat (Anonim,2007).

Automatic Information Notification System (AINS)

AINS system, melakukan pelacakan terhadap variasi parameter keselamatan yang telah dikumpulkan oleh SIDS maupun IERNet system. Jka parameter kritis terlampaui, sistem ini akan mengirim sinyal/peringatan melalui pesan e-mail kepada personel tanggap darurat (Anonim, 2007).

\section{Source Term Estimation System (STES)}

STES system, mengestimasikan radiation source terms seperti pelepasan material radioaktif yang mungkin terjadi keluar tapak fasilitas nuklir, kemungkinan pathways dan jumlah yang terlepas berdasarkan parameter keselamatan real time yang terkumpul melalui SIDS system (Anonim,2007).

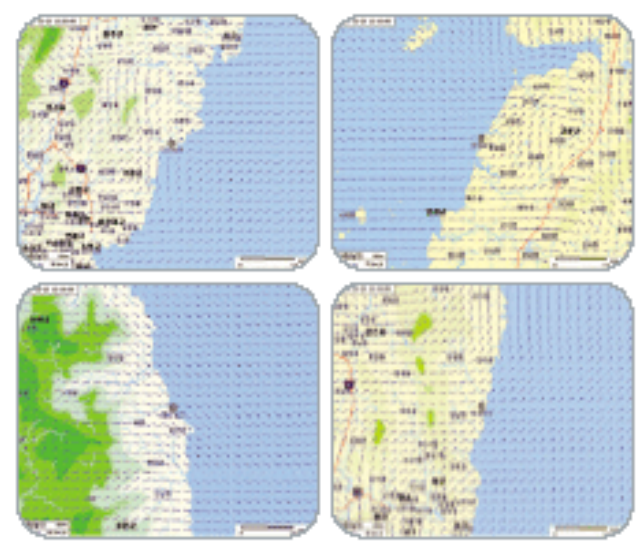

Gambar 4. Medan Angin 3 D 

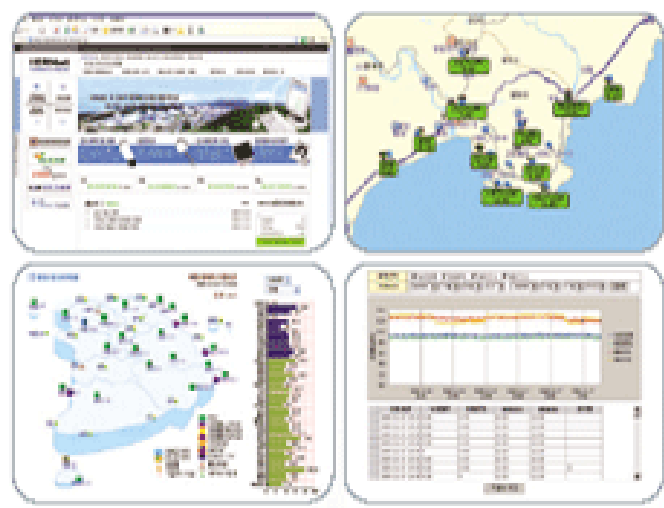

Gambar 5. IERNet System Display
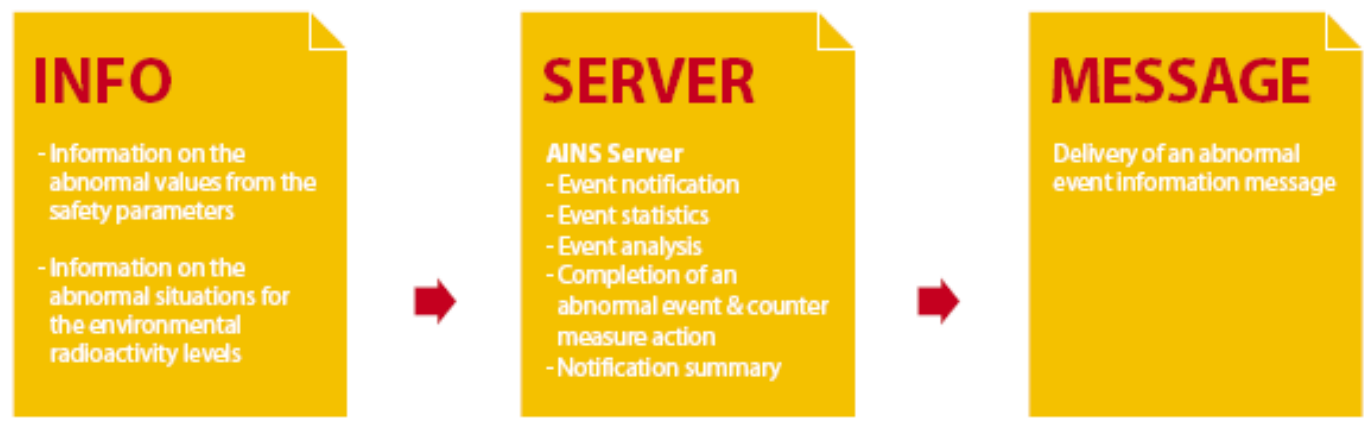

Gambar 6. AINS System

Source Term $=\Sigma\left(\mathrm{FPl}_{1} \times \mathrm{CRF}_{1} \times \mathrm{RDF}_{1} \times \mathrm{EF}_{1}\right)$

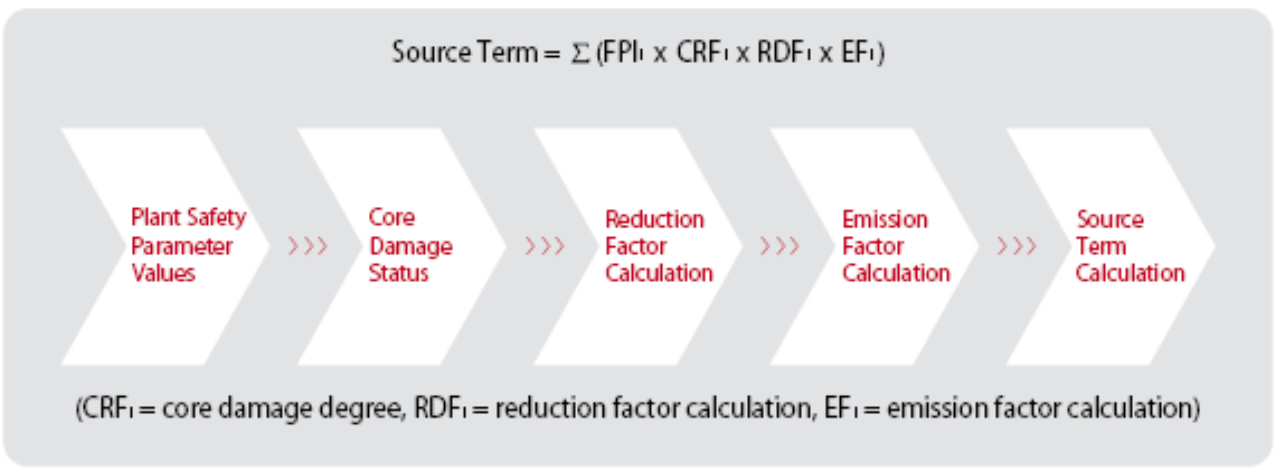

Gambar 7. STES System

\section{Following Accident Dose Assessment System (FADAS)}

Perkiraan dosis paparan yang diterima masyarakat terkait dengan pelepasan material radioaktif ke lingkungan yang berdasarkan pada upaya tanggap darurat, merupakan hal yang penting yang harus dilakukan untuk melindungi mayarakat dan lingkungan. Dosis paparan dihitung dengan menggunakan 3 dimensi medan angin yang memperhitungkan kondisi 
topografi berdasarkan data meteorologi yang tersedia pada REMDAS System dan estimasi STES System. FADAS ditampilkan dalam bentuk grafis dengan informasi geografis untuk memperkirakan luas wilayah yang terkena dampak dan mempersiapkan upaya kedaruratan yang tepat setelah membandingkan hasil pengukuran aktual (Anonim, 2007).

Geographical Information System (GIS)

Untuk mendukung akurasi upaya yang dilakukan dalam tanggap darurat yang dihasilkan oleh FADAS System, diperlukan sistem informasi geografi (GIS) yang terkait dengan socio-environmental (Anonim,2007). Basis data Socio-environmental meliputi; populasi, transportasi, fasilitas industri, sehingga upaya tanggap darurat yang dilakukan akan lebih tepat dan terarah (Gambar 9).

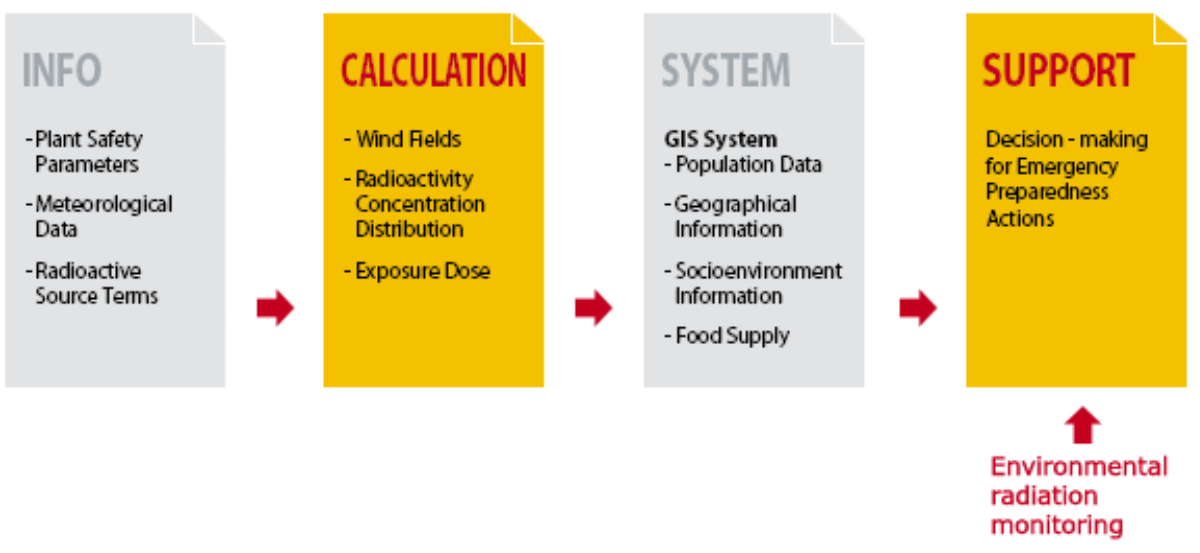

Gambar 8. FADAS System (Anonim, 2007)
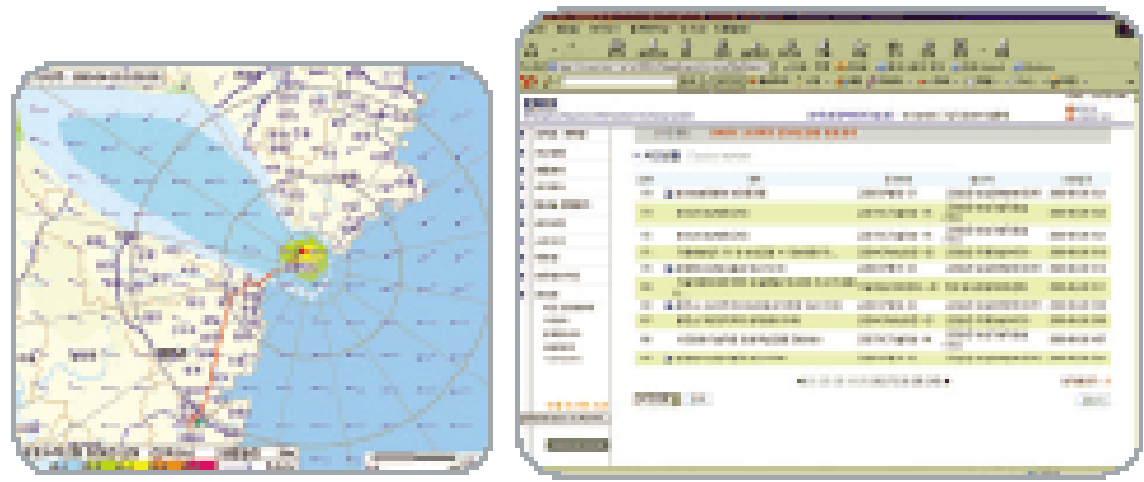

Gambar 9. Display GIS (kiri), ERIX System (Anonim, 2007) 


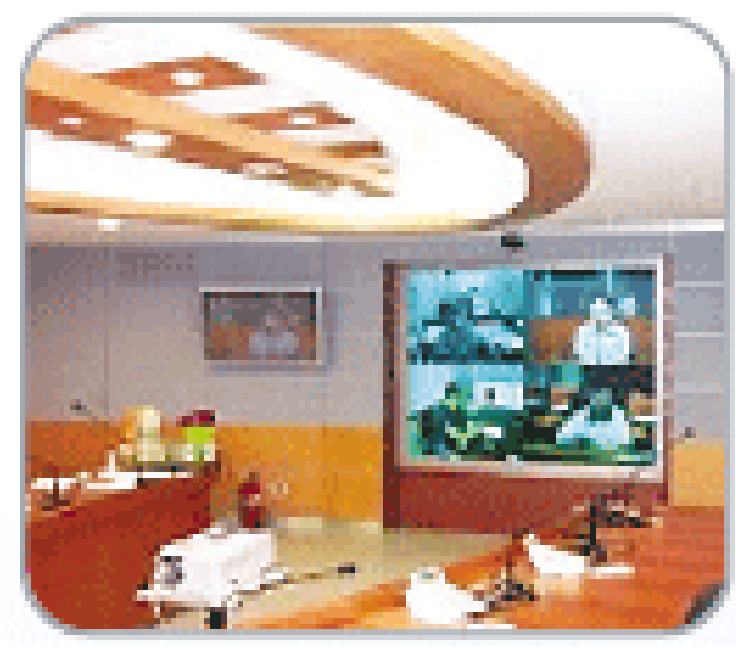

Gambar 10. Video Conf. System

(Anonim, 2007)

\section{Emergency Response Information eXchange (ERIX)}

ERIX system adalah sistem pertukaran informasi berbasis web untuk memudahkan dan mempercepat komunikasi serta berbagi informasi pada setiap kondisi, status kejadian abnormal atau tanggap darurat (Gambar 10). Secara konvensional komunikasi dilakukan dengan menggunakan fax dan telepon antar organisasi terkait. ERIX System bermanfaat dalam berbagi informasi, mempermudah dan mempercepat sistem komunikasi serta dapat dikendalikan jarak jauh.

\section{Video Conference System}

KINS mengoperasikan multi-point video conference system untuk memutuskan suatu keputusan penting yang terkait dengan upaya-upaya perlindungan terhadap penduduk selama terjadinya kedaruratan radiologi (Gambar 11). Sistem ini membantu proses pengambilan keputusan jarak jauh antar lembaga terkait.

\section{Kondisi di Indonesia}

Nilai $\mathrm{N}_{\mathrm{e}} \geq 10^{15} \mathrm{~cm}^{-3}$ berlaku untuk Persamaan Boltzmann dan nilai $\mathrm{N}_{\mathrm{e}}$ $\leq 10^{13} \mathrm{~cm}^{-3}$ untuk kondisi coronal model pada Persamaan 9. Rumus pendekatan yang dapat digunakan untuk memperoleh jumlah atom tereksitasi $\mathrm{N}_{1}^{*}$ dapat ditulis sebagai berikut. yang akan datang Indonesia akan membangun dan mengoperasikan reaktor daya. Salah satu faktor yang menjadi obyek dalam pengawasan pemanfaatan tenaga nuklir adalah radioaktivitas lingkungan.

Keselamatan, keamanan, dan ketentraman, kesehatan pekerja dan anggota masyarakat, serta perlindungan terhadap lingkungan hidup dalam 
pemanfaatan tenaga nuklir akan terwujud apabila sistem keselamatan dan keamanan instalasi bahan nuklir dan fasilitas radiasi dan zat radioaktif memenuhi persyaratan perizinan, dan kedaruratan nuklir dapat ditangani dengan baik serta dilakukan secara terintegrasi. Skenario hipotetis kedaruratan nuklir dapat terjadi akibat kecelakaan nuklir/radiasi yang berasal dari kesalahan atau kelalaian sistem keselamatan atau gangguan/serangan terhadap sistem keamanan (tidak disengaja ataupun disengaja, misalnya serangan teroris) yang dimiliki oleh pemegang izin (PI) atau pengusaha instalasi nuklir (PIN), selain itu kecelakaan nuklir/radiasi dapat berasal dari sumber radioaktif/bahan nuklir yang hilang atau tidak diketahui pemiliknya (misalnya berupa special atomic demolition munition (SADM), radiological dispersal device (RDD), re-entry nuclear satelite). Dalam kenyataannya, banyak kecelakaan yang terjadi baik kecelakaan nuklir/radiasi dan/atau kecelakaan non-nuklir dapat atau berpotensi menimbulkan kedaruratan nuklir. Dalam Pasal 16 ayat 1 Undang-Undang RI No. 10 Tahun 1997 (UU No. 10/1997) tentang Ketenaganukliran dinyatakan bahwa "Setiap kegiatan yang berkaitan dengan pemanfaatan tenaga nuklir wajib memperhatikan keselamatan, keamanan, dan ketentraman, kesehatan pekerja dan anggota masyarakat, serta perlindungan terhadap lingkungan hidup". Sedangkan dalam Pasal 16 ayat 2 Undang-Undang RI No. 10 Tahun 1997 tentang Ketenaganukliran dinyatakan bahwa "Ketentuan sebagaimana dimaksud pada ayat 1 diatur lebih lanjut dengan Peraturan Pemerintah". Sesuai dengan amanat UU No.10/1997 tentang Ketenaganukliran Pasal 14 ayat 2 BAPETEN melakukan pengawasan terhadap pemanfaatan tenaga nuklir melalui peraturan, perizinan, dan inspeksi. Namun demikian, terselenggaranya komponen unsur pengawasan tersebut tidak serta merta menghilangkan secara mutlak kemungkinan terjadinya kecelakaan. Kemungkinan untuk munculnya kecelakaan dapat terjadi kapan saja dan dimana saja, kondisi ini memerlukan kesiapan semua infrastruktur dan kemampuan fungsi penanggulangan yang siap dikomando dan dioperasikan berdasarkan sistem nasional terpadu dari sebuah Organisasi Tanggap Darurat Nuklir Nasional (OTDNN) yang telah ditetapkan. Dengan demikian, tersedianya OTDNN sebagai salah satu unsur Sistem Kesiapsiagaan Nuklir Nasional (SKNN) sangat diperlukan ketersediaanya.

SKNN secara garis besar mengatur ketentuan pembagian dan penetapan tugas dan kewajiban PI, Pemerintah Daerah dan Nasional dalam menjalankan tugas kesiapsiagaan dan tanggap darurat. Tugas kesiapsiagaan untuk masing-masing level penanggung jawab mencakup menyusun dan menetapkan unsur-unsur infrastruktur dan fungsi penanggulangan. Unsur infrastruktur dalam kesiapsiagaan meliputi: penetapan Organisasi Tanggap 
Darurat (OTD) dan koordinasi yang lengkap dengan sumber daya manusia serta uraian tanggung jawabnya, prosedur tanggap darurat, peralatan dan sarana pendukung yang memadai dan program pelatihan yang terpadu. Fungsi penanggulangan sebagai implementasi kemampuan operasional tanggap darurat mencakup kemampuan teknis dalam hal: mengidentifikasi dan mengklasifikasikan kecelakaan, melaksanakan pelaporan, dan tindakan penanggulangan mulai dari tindakan awal, mitigasi, proteksi radiasi pekerja kedaruratan dan masyarakat, langkah upaya pemantauan hingga pemulihan (recovery).

Munculnya kedaruratan yang dapat terjadi dimanapun dan kapanpun sangat membutuhkan tindakan tanggap darurat (respon) yang tepat, cepat, dan efisien. Pemerintah Republik Indonesia melalui 3 buah Keputusan Presiden, yaitu:

1. Kepres No.81/1993 tentang Pengesahan Convention on Early Notification of a Nuclear Accident.

2. Kepres No.82/1993 tentang Pengesahan Convention on Assistance on the Case of a Nuclear or Radiological Emergency.

3. Kepres No.106/2001 tentang Pengesahan Convention on Nuclear Safety.

Bertujuan untuk mencegah dan menanggulangi kecelakaan nuklir secara dini serta memperkecil akibat yang ditimbulkannya. Tujuan ini sesuai dengan ketentuan seperti yang tercantum dalam UU No.10/1997 tentang Ketenaganukliran pasal 16 yang menyatakan bahwa "setiap kegiatan yang berkaitan dengan pemanfaatan tenaga nuklir wajib memperhatikan keselamatan, keamanan, dan ketentraman, kesehatan pekerja dan anggota masyarakat, serta perlindungan terhadap lingkungan hidup".

\section{PEMBAHASAN}

Korea Selatan telah memiliki suatu sistem kedaruratan radiologi yang telah terintegrasi baik secara kelembagaan maupun secara teknis. Secara kelembagaan Korea Selatan telah memberdayakan berbagai sumberdaya manusia (SDM), teknis dan manajemen.

Indonesia, melalui keputusan Kepala BAPETEN no. 14 tahun 2007 tentang Satuan Tanggap Darurat, telah menetapkan dokumen teknis berupa Prosedur Tanggap Darurat. Sementara itu ketentuan yang mengatur tentang manajemen kedaruratan radiologi -RPP tentang Sistem Kesiapsiagaan Nuklir Nasional- sedang disusun. Dalam dokumen teknis tersebut telah ditetapkan infrastruktur yang diperlukan dalam kedaruratan radiologi.

Hingga tulisan ini diturunkan, sedang disusun dokumen yang mengatur tentang organisasi nasional yang terlibat dalam kedaruratan radiologi yang 
disebut dengan pedoman operasi organisasi tanggap darurat nuklir nasional (OTDNN). Dalam rencana pedoman tersebut yang akan terlibat dalam OTDNN antara lain:

1. Departemen Kesehatan (Depkes)

2. Departemen Pertanian (Deptan)

3. Departemen Perhubungan (Dephub)

4. Departemen Sosial (Depsos)

5. Tentara Nasional Indonesia (TNI)

6. Departemen Pekerjaan Umum (DepPU)

7. Departemen Dalam Negeri (Depdagri)

8. Departemen Kelautan dan Perikanan (DKP)

9. Badan Pengawas Obat dan Makanan (BPOM)

10. Badan SAR Nasional (BASARNAS)

11. Kementrian Negara Lingkungan Hidup (KLH)

12. Polisi Republik Indonesia (POLRI)

13. Ambulance 118

14. Pemadam Kebakaran (PMK)

15. Pengkaji Radiologi

16. Batan Tenaga Nuklir Nasional (BATAN)

17. Kompi Nubika TNI-AD

18. Badan Meteorologi dan Geofisika (BMG)

19. BAPETEN

Dari segi perangkat peraturan kedaruratan, sudah bisa diimplementasikan dalam bentuk manajerial. Namun dari aspek sistem dan teknologi pengawasan serta pendukung teknis kedaruratan masih perlu dibentuk dan dikembangkan lebih jauh lagi sesuai dengan kebutuhan nasional.

Care system memiliki sistem pendukung yang komprehensif, baik sistem, teknologi, maupun hubungan antar lembaga yang terkait. Hal ini dapat dijadikan rujukan bagi Indonesia untuk membangun dan mengembangkan sistem kedaruratan nuklir nasional.

Kondisi SDM pada masing-masing lembaga terkait perlu ditingkatkan kapabilitasnya agar dapat mendukung sistem kedaruratan yang akan dibangun dapat berjalan dengan baik. Dalam peningkatan kapabilitas SDM pada masing-masing lembaga harus dilakukan secara integral. 


\section{KESIMPULAN}

Sistem pendukung teknis kedaruratan yang telah dikembangkan Korea Selatan (Care system) dapat digunakan sebagai bahan pertimbangan dalam membangun sistem pendukung teknis kedaruratan radiologi di Indonesia.

Perlu pengembangan SDM nasional yang memahami secara integral kebutuhan terkait kedaruratan radiologi, terutama terkait dengan sistem informasi, teknologi pengawasan dan koordinasinya.

Perlu dikaji kebutuhan jangka pendek, menengah dan jangka panjang yang terencana terkait dengan kedaruratan radiologi.

\section{DAFTAR PUSTAKA}

1. ANONIM, 1997."Undang-undang no 10 tahun 1997 tentang Ketenaganukliran", BAPETEN, Jakarta.

2. ANONIM, 2007. "Draft RPP tentang Sistem Kesiapsiagaan Nuklir Nasional", BAPETEN, Jakarta.

3. ANONIM, 2007. "PerKa BAPETEN no 14/2007 tentang Satuan Tanggap Darurat", BAPETEN, Jakarta.

4. ANONIM, 2007. "Care system", http://CARE.kins.re.kr.

5. ANONIM, 2007. "Juklak Tindakan Perlindungan Mendesak (Urgent Protection Action-UPA) Kecelakaan Reaktor Nuklir”, DKKN BAPETEN, Jakarta. 
